\title{
Nilai Penting Atap Kubah dan Denah Oktagonal pada Gereja Blenduk - sebuah studi awal-
}

\section{Significance Value of the Dome Roof and Octagonal Plan of Blenduk Church - a preliminary study -}

\author{
Yohanes Khrisna Hadi Putra \\ ERTIM Conservation Institute \\ yohanes.khrisna.hadi.putra@gmail.com
}

\begin{abstract}
ABSTRAK
Bangunan G.P.I.B. Semarang yang lebih dikenal dengan Gereja Blenduk memiliki dua elemen penting pembentuk karakter bangunan, yakni atap kubah dan denah oktagonal. Atap dan denah adalah karakter penting pembentuk arsitektur bangunan. Perubahan bentuk dan bahan dua elemen tersebut pada Gereja Blenduk telah mengindikasikan adanya proses memahami lingkungan tropis pada era kolonial (abad ke-18 sampai ke-19), secara spesifik di Kota Lama Semarang. Melalui pendekatan arkeologi bangunan, penulis hendak mengungkap asal-usul bentuk dua elemen tersebut dan kontribusinya terhadap nilai penting Gereja Blenduk.
\end{abstract}

Kata Kunci: atap kubah, denah oktagonal, gereja blenduk

\begin{abstract}
The G.P.I.B. Semarang building, better known as the Blenduk Church, has two important elements that defining building character, a dome roof and octagonal plan. Roof and plan are important character shaped building architecture, The changes in shape and material of the two elements at Blenduk Church, have indicated the process of understanding tropical environment in the colonial era $\left(18^{h}-19^{h}\right.$ century), specifically on Semarang old town. Through the building archeology approach, the author wants to reveal the origin of the two elements form, and their contribution to the significant value of Blenduk Church.
\end{abstract}

Keywords: dome roof, octagonal plan, blenduk church

\section{PENDAHULUAN}

Bangunan gereja sangat erat kaitannya dengan pembentukan kotakota kolonial di Hindia Belanda, terutama pada era V.O.C. Di awal abad ke-18, V.O.C memindahkan kantor Gubernur dari Jepara ke Semarang (Keijzer, 1862: 277). Diduga lokasi Gereja Blenduk terkini sudah ada sejak abad ke-18. Wujud arsitektur Gereja Blenduk berasal dari geometri dasar berupa segi delapan dan kubah, yang tidak lepas dari pengaruh dan dinamika yang terjadi di Belanda dan Batavia. Dengan penelusuran terhadap literatur, arsip digital teks koran, dan data pemindaian laser $3 \mathrm{~d}$, didapatkan data-data baru di dalam menginterpretasikan kembali sejarah bentuk bangunan. Dari pendekatan tersebut, penulis hendak menelusuri asal usul dua elemen penting tersebut diadopsi dalam bangunan Gereja Blenduk, sekaligus meninjau ulang 
narasi arsitektur Gereja Blenduk yang sebelumnya pernah ditulis.

\section{Sejarah Bangunan}

Pada tahun 1753 gereja protestan pertama di Semarang resmi dilembagakan'. Pendeta pertamanya adalah Johannes Wilhelmus Swemmelaar (1753-1760) yang mulai melayani jemaat di Semarang. Jemaat gereja pada awalnya adalah komunitas Eropa yang terdiri dari pegawai, pejabat, dan tentara V.O.C. Gereja protestan ini merupakan bagian dari Gereja Reformasi (Nederlandsch Hervormde Kerk) yang berpusat di Belanda. Semarang pada masa itu adalah kota pelabuhan V.O.C2. Di masa V.O.C hanya Gereja Reformasi yang diijinkan untuk mendirikan bangunan di dalam wilayah kekuasaannya. Gereja protestan ini kemudian lebih dikenal sebagai Protestanche Gemeente te Semarang atau Protestansche Koepelkerk te Semarang.

Informasi awal mengenai gereja dan bangunannya sangat terbatas, laporan tertua mengenai kondisi bangunan Gereja Blenduk berasal dari tahun 1758, yakni catatan V.O.C tanggal 24 Juni. Dalam laporan tersebut bangunan tersebut mengalami kerusakan serius karena semut putih ${ }^{5}$ dan mendesak untuk diperbaiki. Kepala tukang kayu Surakarta yang bernama Johan

De Indische Courant, 7 Juni 1928

Protestantse Gemeente Te Semarang 200

Jaar. Trouw, 25 Agustus 1953

3

Heuken, 2003: 11

Soleiman, 2012: 194

5 kemungkinan ini adalah rayap
Nicolaas Keijser dipanggil ke Semarang untuk mengestimasi biaya perbaikan. Untuk alasan keselamatan, ibadah hari Minggu dipindahkan ke bangunan lain selama perbaikan berlangsung.

Pihak konsistori gereja menyampaikan perihal tersebut kepada H. Carel Godin, kepala administratif dan komando kedua pemerintah Semarang, yang juga bertanggungjawab sebagai pengawas gereja (churchwarden). Bangunan tersebut dalam kondisi rawan runtuh setelah hujan deras, angin, dan gempa bumi. Mereka berpendapat bahwa diperlukan pembangunan delapan pilar kayu baru dan besar pada pondasi batu untuk menggantikan yang sebelumnya. Hal itu berarti juga bagian bawah bangunan perlu ditarik keluar.

Laporan lainnya tentang kondisi bangunan berasal dari tahun

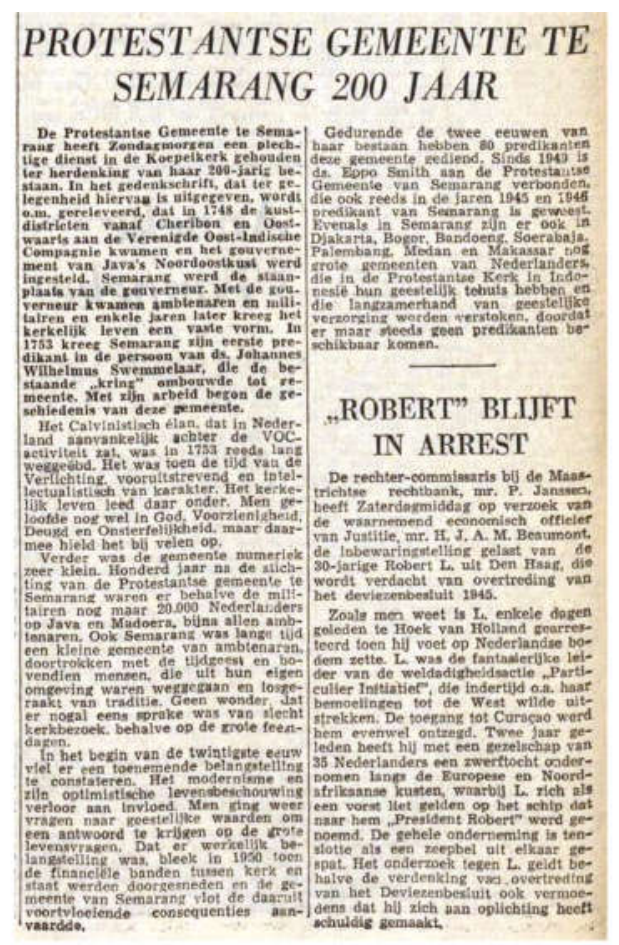

Gambar 1. Gambar 1. Kliping surat kabar Trouw, 25 Agustus 1955 (sumber:www.delpher.nl) 
1772. Saat itu arsitek Frederik Justman mengatakan ada kebocoran di beberapa titik setelah pemindahan beberapa penutup atap, dan air hujan masuk sampai ke dinding dalam bangunan. Ia juga mencatat bahwa ada kesulitan untuk mendengar suara menteri karena pantulan yang tidak teratur, sehingga diusulkan untuk penyesuaian ulang. Perbaikan selanjutnya dilakukan pada tahun 1785, dan masih berkutat di bagian atap, yang memakan waktu lebih lama. Berdasarkan data sejarah tersebut, elemen bangunan yang diperhatikan adalah atap dan pilar bawah atap. Diduga bentuk awal denah utama terdiri dari delapan pilar kayu dan bentuk atap belum jelas, serta bahan penutup atap juga tidak disebutkan, namun diduga kuda-kuda kayu atap berbahan kayu.

Pada tahun 1787, di tempat bangunan gereja pertama didirikan, direncanakan pendirian bangunan gereja baru. Bangunan gereja pertama dibongkar, dan didirikan bangunan gereja baru yang memiliki denah berbentuk segi delapan dan atap berbentuk kubah. Bangunan gereja yang baru ini ditahbiskan pada 19 Oktober 1795 oleh Pendeta Fredericus Montanus (1778-1814) yang melayani pada saat itu. Pada malam hari tanggal 10 Juni 1867, terjadi gempa bumi yang mengguncang Yogyakarta dan Jawa Tengah. Bangunan gereja turut mengalami kerusakan yang cukup parah akibat gempa tersebut. Dua menara gereja runtuh, dinding mengalami retak, dan sirap atap kubah rusak $^{6}$. Bangunan gereja yang

${ }^{6}$ De Locomotief, 19 Augustus 1953 rusak tidak segera diperbaiki karena pada saat itu gereja mengalami masalah keuangan, sementara kota tidak memiliki dana untuk perbaikan. Pada 15 Agustus 1869 dewan gereja memutuskan untuk sementara menutup gereja. Tidak lama setelah penutupan gereja, di tahun yang sama pada tanggal 24 Desember dewan gereja memutuskan untuk merobohkan bangunan gereja yang rusak untuk mendirikan bangunan baru. Rencana ini belum sempat terlaksana karena gereja memperoleh dana untuk perbaikan.

Empat tahun setelah perbaikan, 25 Juni 1871 bangunan gereja dapat digunakan kembali untuk beribadah. Empat tahun setelahnya, pada malam 16 April 1875 bangunan gereja tersambar petir yang menyebabkan atap bangunan gereja terbakar. Kala itu dewan gereja memiliki dana untuk melakukan perbaikan, sehingga bagian yang rusak dapat segera diperbaiki. Pada 12 Desember 1890 terjadi gempa bumi yang mengguncang Juwana Pati . Gempa tersebut menyebabkan bangunan gereja yang telah diperbaiki rusak kembali. Akhirnya diputuskan untuk merombak besar-besaran bangunan gereja. Kali ini dewan gereja berhasil mengumpulkan dana hingga 60.000 gulden.

Pekerjaan rehabilitasi memakan waktu sekitar dua tahun, dimulai tahun 1894 sampai 1895. Perancangnya adalah H.P.A de Wilde seorang ahli ukur dan W.Westmas seorang arsitek sipil. Rehabilitasi ini tidak banyak mengubah bangunan asli yang sudah

${ }^{7}$ De Locomotief, 16 Desember 1890 
ada sejak tahun 1794. Rehabilitasi yang dilakukan meliputi penambahan portico (teras) dan menara di bagian muka, penggantian atap kubah, penggantian kusen daun pintu dan jendela serta penggantian kaca dengan kaca patri. Tambahan pediment (semacam gunungan) dengan empat kolom tuscan sebagai portico memperkuat gaya neo klasik pada bangunan ini.

Dua menara yang runtuh ketika gempa tahun 1869 dibangun kembali menjadi menara jam (klokken toren). Sedangkan bagian atap yang mengalami kerusakan beberapa kali, diganti atap kubah baru yang terbuat dari plat metal menggantikan atap lama dari sirap kayu. Plafon bilah kayu yang juga berbentuk kubah dengan ornamen di tengahnya menambah keindahan di bagian interior. Kusen Pintu transept yang awalnya berbentuk kotak, diganti model lengkung (arch) dengan bovenlicht isi kaca patri. Pada kusen jendela, perubahan terjadi pada

Tabel 1. Riwayat pembangunan koepelkerk Semarang

\begin{tabular}{cl}
\hline Tahun & \multicolumn{1}{c}{ Peristiwa } \\
\hline 1753 & dugaan bangunan awal berdiri \\
\hline 1787 & $\begin{array}{l}\text { perencanaan bangunan gereja } \\
\text { baru }\end{array}$ \\
\hline 1794 & $\begin{array}{l}\text { bangunan gereja baru telah } \\
\text { berdiri }\end{array}$ \\
\hline 1867 & $\begin{array}{l}\text { gempa bumi, bangunan gereja } \\
\text { mengalami kerusakan }\end{array}$ \\
\hline 1871 & $\begin{array}{l}\text { bangunan gereja } \\
\text { diperbaiki }\end{array}$ \\
\hline 1875 & $\begin{array}{l}\text { bangunan gereja tersai } \\
\text { petir }\end{array}$ \\
\hline 1890 & $\begin{array}{l}\text { gempa bumi, bangunan gereja } \\
\text { mengalami kerusakan }\end{array}$ \\
\hline $1894-1895$ & $\begin{array}{l}\text { rehabilitasi besar (atap kubah } \\
\text { baru, jendela baru, portico, } \\
\text { menara baru) }\end{array}$ \\
\hline $2002-2003$ & $\begin{array}{l}\text { rehabilitasi oleh pihak G.P.I.B } \\
\text { Immanuel Semarang }\end{array}$ \\
\hline
\end{tabular}

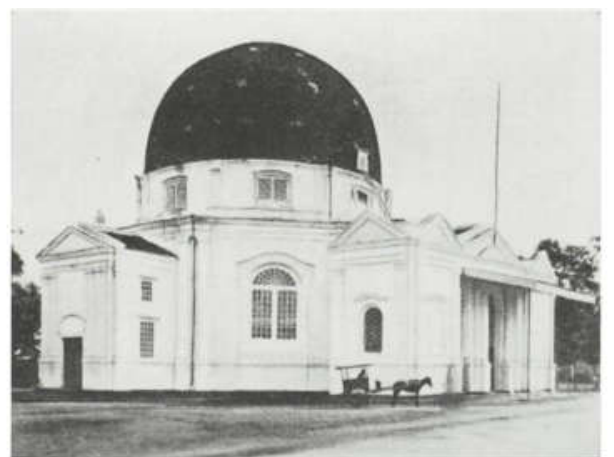

Gambar 2. Foto lama Gereja Blenduk sebelum direhabilitasi

(Sumber : Locale Techniek, 1939, Vol. 008, Issue 6)

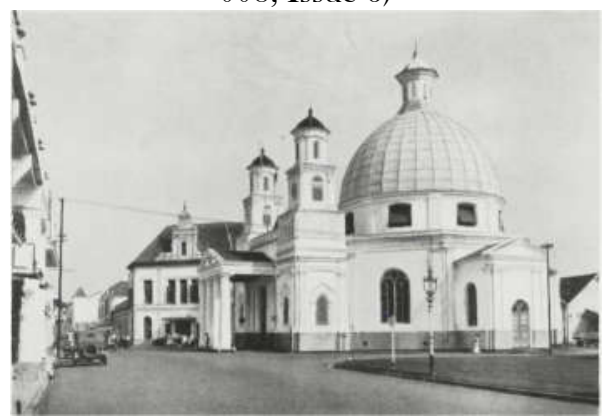

Gambar 3. Foto lama Gereja Blenduk setelah direhabilitasi

(Sumber : Locale Techniek, 1939, Vol. 008, Issue 6)

bentuk isian kusen yang menyesuaikan dengan bentuk lengkung (arch) dan kaca patri baru. Setelah gereja selesai direhabilitasi, diletakkan prasasti dari marmer di kolom dekat altar yang memuat tahun rehabilitasi beserta nama-nama pejabat gereja dan arsitek perancangnya. Atap kubah dan denah oktagonal bangunan Gereja Blenduk saat ini adalah bangunan yang telah direhabilitasi tahun 1894-1895 dan 2002-2003. Kemungkinan besar berbeda dengan bangunan awal yang didirikan pada tahun 1795. Bangunan tidak mengalami perubahan fungsi sejak awal hingga saat ini, yaitu sebagai tempat ibadah. 


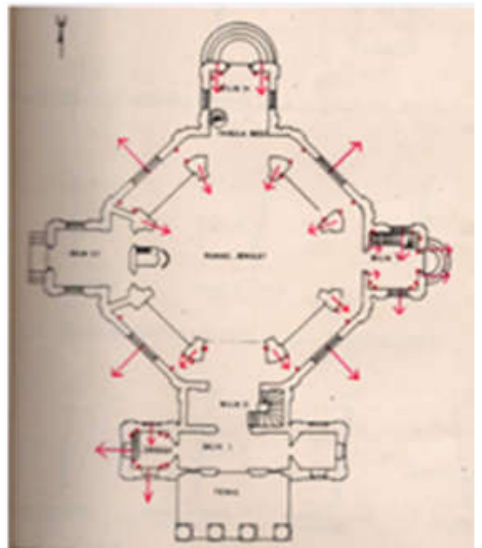

Gambar 4. Denah arah kemiringan dinding Gereja Blenduk

(Suaka Purbakala Jateng sebelum 1989)

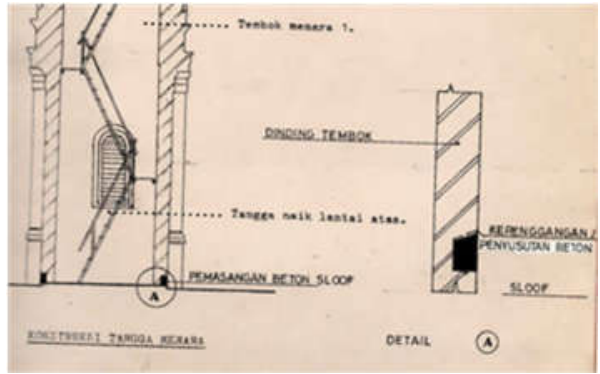

Gambar 5. penambahan sloof beton bertulang pada bagian bawah dinding (Suaka Purbakala Jateng sebelum 1989)

Laporan yang cukup menggambarkan kondisi stabilitas dinding pernah dilakukan oleh Suaka Purbakala Jawa Tengah di tahun 1989. Pengamatan dilakukan pada dinding bangunan yang terdapat keretakan, penelupasan plesteran, rumah rayap, dan kebocoran atap. Selain itu dilakukan pula pengukuran derajat kemiringan pada dinding struktural. Dari hasil pengamatan, ditemukan 11 lokasi keretakan, sebagian besar terdapat pada sisi Timur dan Selatan, dan berada di atas pintu dan jendela. Berdasar pengamatan sepintas, bila sigma tanah dan kondisi bata cukup kuat, diduga karena pembobokan, getaran kendaraan, dan penyusutan sloof beton bertulang yang telah dipasang. Secara teknis, keretakan dan kemiringan dinding dianggap tidak membahayakan karena penyusutan beton relatif kecil dan proses konsolidasi diperkirakan sudah terhenti. Namun demikian perlu dilakukan penelitian mengenai dampak dari pemasangan sloof tersebut. Dengan kata lain diperlukan adanya pendataan berulang-ulang pada titik yang sama agar dapat dievaluasi hasilnya kemudian.

\section{Kondisi Terkini}

Gereja Blenduk terletak di Jl. Letjend. Soeprapto No. 32 Kawasan Kota Lama Semarang. Jalan Letjend Soeprapto yang berada di depan Gereja Blenduk dahulu bernama Heerenstraat merupakan jalan utama. Terletak pada koordinat X: 436774.897 dan Y: 9229724.12. Gereja Blenduk merupakan bangunan denah ruang utama berbentuk segi delapan dengan ruangruang tambahan ke empat sisinya (utara, timur, selatan, dan barat). Situs tersebut memiliki luas $1137,37 \mathrm{~m}^{2}$, dengan luas lantai dasar bangunan $616,104 \mathrm{~m}^{2}$, dan tinggi keseluruhan sekitar 31,35 m. Selain digunakan untuk kebaktian setiap hari minggu, pada hari-hari biasa Gereja Blenduk digunakan untuk kegiatan-kegiatan gereja seperti pelayanan, latihan paduan suara, dan persekutuan doa. Gereja Blenduk saat ini dikelola oleh G.P.I.B. Immanuel Semarang, serta telah ditetapkan sebagai Bangunan Cagar Budaya di bulan Oktober tahun 2018.

Studi tentang Gereja Blenduk masih terbatas pada bidang arsitektur, seperti identifikasi elemen-elemen penting bangunan secara arsitektural serta melakukan pembobotan nilai 


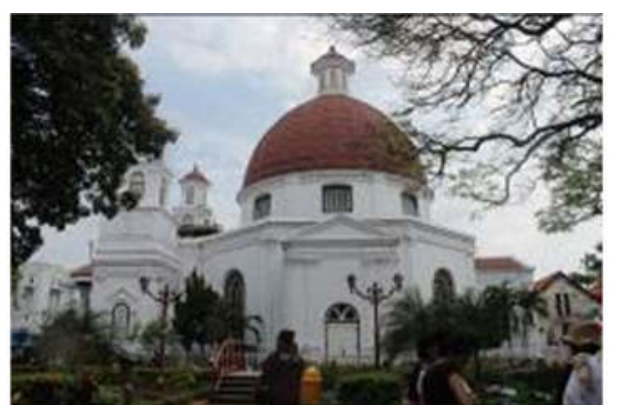

Gambar 6. Gereja Blenduk dari Taman Srigunting

(Sumber : Dokumentasi ERTIM, 2018)

makna arsitekturalnya (Tanjungsari et all, 2016), Gereja Blenduk sebagai tetenger (Moedjiono dan Indriastjario, 2011), dan pengaruh budaya Indische pada interior Gereja Blenduk (Wardani dan Triyulianti, 2012). Hal-hal terkait kemasa-laluan seperti alasan Gereja Blenduk dibangun, alasan terletak di posisi yang sekarang, alasan muncul bentukan yang seperti itu, belum pernah diungkap.

\section{METODE}

Penelitian terhadap objek Gereja Blenduk dilakukan sejak September tahun 2018. Pada tahap pengumpulan data dilakukan tiga cara. Pertama, dengan menelusuri arsip digital era kolonial. Kata kunci yang dipilih adalah "koepelkerk", "protestansche kerk", dan "semarang" pada situs www.colonialarchitecture.eu dan www.delpher.nl. Kedua, untuk mendapatkan rekaman bentuk bangunan, metode dokumentasi yang dipilih adalah dengan menggunakan pemindaian 3d laser. Alat yang dipilih adalah Leica BLK360, sedangkan untuk pemrosesan data pointcloud digunakan piranti lunak Autodesk Recap Pro. Untuk mendapatkan lokasi koordinat, digunakan GPS geodetik Leica GS14L. Ketiga mencari literasi baik buku ataupun jurnal yang masih berkaitan dengan konteks secara periode waktu maupun bentuk tinggalan. Sedangkan pada tahap analisis data, dilakukan dengan metode kualitatif, deskriptif eksploratif, dan pendekatan arkeologi bangunan.

Pemindaian laser adalah teknik mengukur koordinat dari titiktitik tiga dimensi (3D) pada permukaan objek, dengan menggunakan laser dari posisi mana pun, tanpa bersinggungan langsung dengan objek. Data pointcloud (titik awan) adalah kumpulan titik koordinat 3D dari permukaan objek yang dihasilkan melalui proses pemindaian laser, fotogrametri, atau total station8.

Arkeologi bangunan dapat menjadi pendekatan yang efektif ketika bukti lain, seperti naskah tertulis atau gambar dalam kondisi tidak lengkap atau hilang. Sehingga tindakan survei adalah langkah dasar dan penting dalam arkeologi bangunan. Tujuan dari arkeologi bangunan adalah untuk mengklarifikasi sejarah dari perencanaan dan pembangunan sebuah konstruksi struktur. Selain itu untuk mengetahui periwayatan fase bangunan, rekonstruksi fungsi bangunan di awal, perubahannya, dan identifikasi teknologi bangunan sampai pada menduga terjadinya kerusakan'. Arkeolog bangunan umumnya memiliki perhatian khusus pada elemen atap, karena tanpa atap, tidak ada arsitektur. Atap adalah yang pertama dan terpenting dari fungsi

Grussenmeyer, 2016:305-306

${ }^{9}$ Schuller, 2002:7 
sebuah perlindungan sekaligus yang terancam kerusakan. Oleh karena itu, pembahasan akan difokuskan pada elemen atap kubah dan denah oktagonal, karena dua hal tersebut yang menjadi karakter bangunan, masih dalam kondisi utuh dan relatif otentik.

\section{HASIL PENELITIAN}

\section{Sekilas tentang Arkeologi Bangunan}

Perhatian ilmu arkeologi pada bangunan bersejarah sudah terjadi sejak pertengahan abad ke-19 di Inggris dan Amerika (Hicks and Horning:2006, 273). Di dalam jurnalnya, istilah arkeologi bangunan dimunculkan sebagai perkembangan dari arkeologi sejarah, yang berfokus pada mengkaji hubungan lingkungan terbangun dengan manusia. Pada waktu itu di Inggris, gerakan untuk menjaga warisan arsitektur dipengaruhi oleh adanya perselisihan pandangan tentang bagaimana memperlakukan bangunan bersejarah, antara John Ruskin dan William Morris, yang berujung pada berdirinya Society for the Protection of Ancient Buildings (SPAB) di tahun 1877 dan National Trust di tahun 1895. Selain itu seorang tokoh Robert Machin melakukan kerja arkeologi sampai dengan investigasi sejarah pada rumah-rumah tradisional melalui penekanan pada pondasi Monmouthshire Houses di tahun 1960-1970. Hasil studi tersebut relatif berupa tipologi bangunan. Metodologi yang sering digunakan adalah dengan melacak mundur (regresi) peta lama, fotografi, gambar survei terukur, dan deskripsi tertulis. Selain itu, terkadang memerlukan analis spesialis seperti cat arsitektural atau bahkan ahli dendrokronologi (lingkar tahun kayu). Pekerjaan- pekerjaan arkeologi yang mulai memperhatikan bangunan bersejarah terus berlanjut di tahun 1970, sampai muncul istilah arkeologi bangunan yang memang hanya berfokus pada bangunan-bangunan medieval (abad ke-16-17), yang berbeda jauh ketika di awal yakni tentang rumah domestik vernakuler.

Di Amerika Utara, khususnya di wilayah New England dan Virginia mulai memperhatikan warisan arsitektur di pertengahan abad ke-19 (Hicks and Horning:2006, 273). Saat itu studi arkeologi sejarah berkaitan erat dengan studi bangunan bersejarah. Gerakan kepedulian juga mulai diinisiasi oleh Mount Vernon Ladies Association (berdiri 1853), Assocation for the Preservation of Virginia Antiquities (berdiri 1890) dan Society for the Preservation of New England Antiquities (berdiri 1911). Objek yang diperhatikan relatif berupa rumah tinggal orang biasa pada umumnya namun telah melewati usia yang panjang, daripada rumah seorang politisi. Pandangan tersebut identik dengan colonial revival movement, yang muncul saat pergeseran industri dan imigrasi di New England dan the South, yang diimajinasikan seperti di era kolonial walaupun situasi saat itu jauh dari konteks tersebut. Diantara tahun 1930-1960, di wilayah Virginia dan New England diadakan sebuah proyek arkeologi sejarah, terutama pada situs-situs penting yang berkaitan dengan pra-kolonial Amerika dan yang terdapat sebaran bangunan bersejarah. Lokasi bangunan yang terkenal saat itu adalah di Williamsburg dan dekat Jamestown. Selama proyek tersebut berlangsung arkeologi sejarah Amerika Utara berhasil didefinisikan dengan baik 


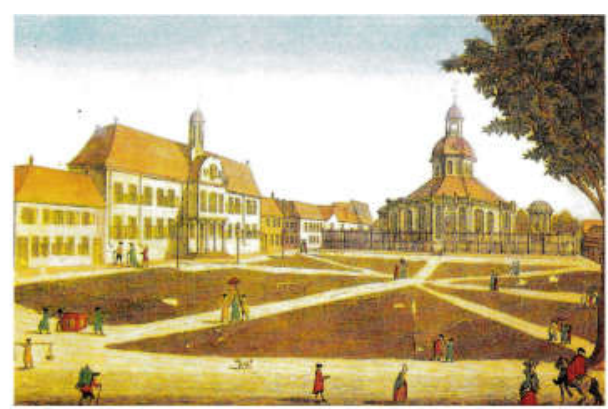

Gambar 7. Lukisan G.M. Probst yang melukiskan Balai Kota dan Gereja Kubah

(Sumber : Gereja-gereja tua di Jakarta, 2003)

melalui tinggalan bangunan yang masih berdiri. Hal tersebut menginspirasi penggunaan metode ekskavasi sebagai bantuan di dalam mengungkap dan melakukan validasi data dalam mendefinisikan arkeologi sejarah. Pada tahun 1934 berdirilah Historic American Building Survey (HABS), yakni program dari pemerintah federal yang bertugas untuk mendokumentasikan warisan arsitektur.

\section{Atap Kubah}

Atap kubah pertama di Hindia Belanda mulai ada sejak pertengahan abad ke-18 di Batavia. Hal tersebut diketahui melalui lukisan karya G.M. Probst. Disitu digambarkan situasi sekitar koepelkerkdan balai kota yang saat ini menjadi Museum Fatahillah. Diceritakan bahwa penutup atap menggunakan lapisan batu tulis yang diimpor dari Eropa. Namun ketika masa V.O.C dibubarkan, kondisi fisik gereja sudah parah. Ada niatan untuk diperbaiki akan tetapi Daendels saat itu memerintahkan agar gedung tersebut dijual, serta memindahkan batu nisan-nisan yang ada di dalam ke daerah Tanah Abang ${ }^{10}$.

10

Heuken, 2003: 25

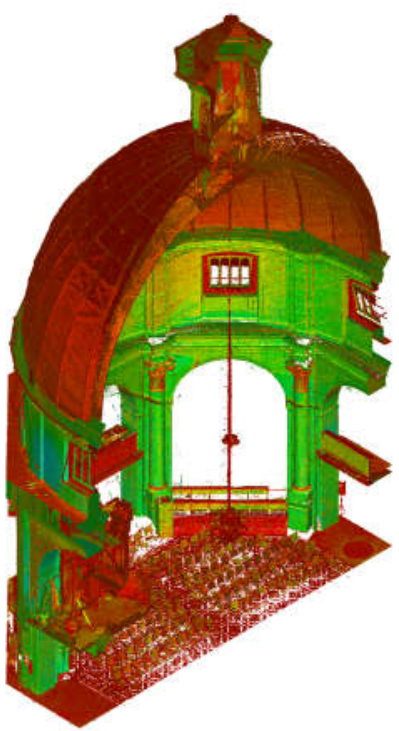

Gambar 8. Data pointcloud potongan isometri denah oktagonal sampai atap kubah

(Sumber : Dokumentasi ERTIM, 2018)

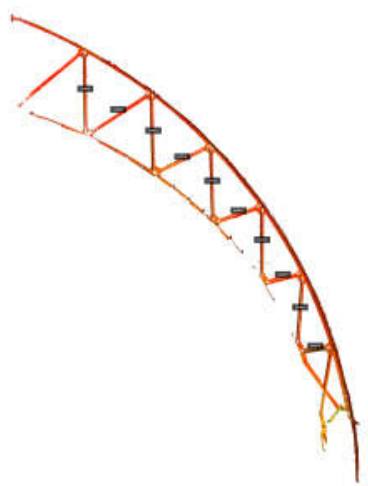

Gambar 9. Data pointcloud rangka atap

(Sumber : Dokumentasi ERTIM, 2018)

Data hasil pemindaian laser, mengungkapkan ada dua lapis kubah. Yang pertama adalah kubah plafon, dengan diameter 15,82 meter, dan kedalaman kubah 8,32 meter diukur dari titik tengah tamboer. Konstruksi plafon turut ditopang dengan rangka kayu melengkung yang mengikuti jarijari kubah. Isian plafon berupa bilah papan kayu yang disusun mengikuti jalur masing-masing sisi oktagonal yang mengerucut ke bagian pusat kubah. Berdasarkan data pointcloud, 
luasan kubah plafon k.l 325,09 meter persegi. Lapisan kedua berupa penutup atap dengan bahan metal ${ }^{11}$ yang dipasang secara melingkar di tiap tingkatan, lapisan ini memiliki diameter kubah 17,26 meter dengan kedalaman kubah 10,24 meter diukur dari titik tengah tamboer. Diantara dua lapisan tersebut, ada konstruksi rangka atap berbahan baja dengan elemen batang diagonal, yang mengikuti jari-jari kubah. Konstruksi tersebut adalah elemen penting di dalam menghubungkan dua lapis kubah sekaligus meneruskan beban ke struktur tamboer di bawahnya. Berdasarkan data pointcloud, luasan penutup atap kubah k.l 425,6 meter persegi.

Pada masing-masing kutub kubah, terhubung dengan elemen kupola diatasnya melalui tiang lampu yang saling berkait dan menerus dari atas kupola sampai dengan tengahtengah interior. Tipologi konstruksi kubah tersebut tergolong kubah rusuk dengan cincin diagonal.

Referensi lain dari konstruksi

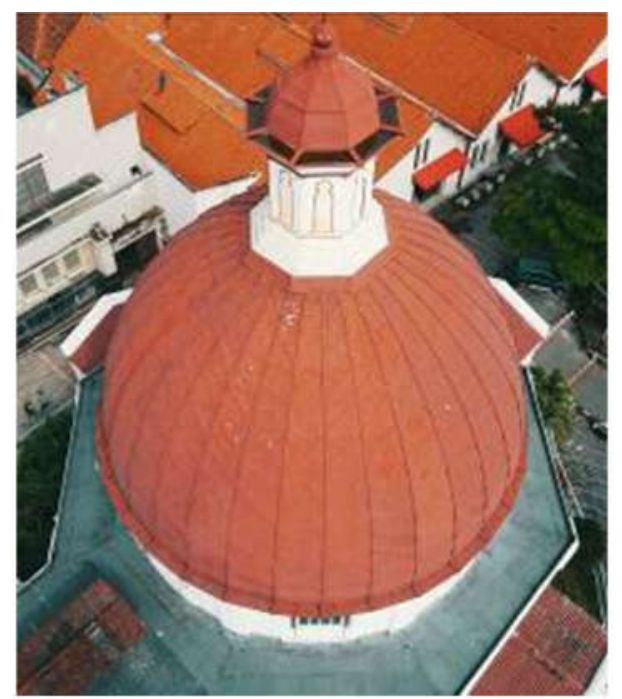

Gambar 10. Atap kubah Gereja Blenduk (Sumber : Dokumentasi ERTIM, 2018)

11

diduga berbahan timah atap kubah adalah yang berbahan kayu. Konstruksi atap kubah dari

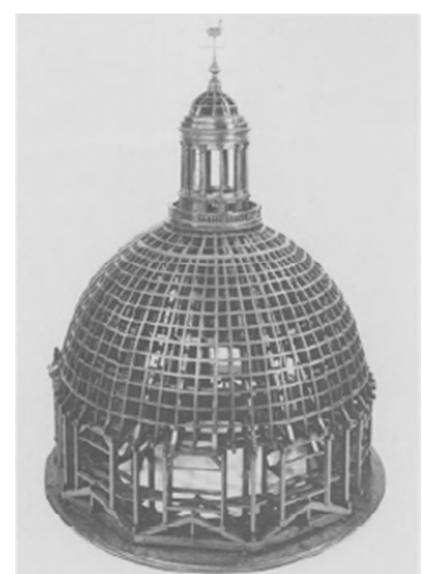

Gambar 11. Maket kubah Gereja New Lutheran, 1823-1824

(Sumber : Houten Kappen In Nederland 1000-1940, 1989)

kayu masih digunakan sampai dengan abad ke-19. Contoh pertama dari tipe ini adalah kubah Gereja New Lutheran di Amsterdam. Konstruksi kubah kayu berfungsi sebagai penghubung antara penutup atap berbahan tembaga dan plafon tipe kaset. Kubah kayu bersandar pada konstruksi kayu yang kaku dan melingkar, berfungsi sebagai tamboer yang meneruskan beban ke pilar dan dinding dibawahnya. Arsitek yang merancang kubah tersebut bernama Jan De Greef (Janse, 1989: 321). Atap kubah Gereja Blenduk dan Gereja New Lutheran sama-sama memiliki dua lapis kubah, namun berbeda bahan penyusun baik pada rangka kubah maupun penutup atap.

\section{Denah Oktagonal}

Menara angin yang terletak di Athena adalah bangunan dengan bentuk denah oktagonal awal, yang diidentifikasi telah muncul sejak era abad ke-2 SM. Bangunan religius dengan bentuk denah segi delapan juga sudah ada di abad ke-4, yakni 
kuil Diocletian di Spalato, Kapel Kenaikan (Chapel of Ascension) di Yerusalem, Gereja Kelahiran (Church of Nativity) di Betlehem. Dalam agama Kristen, angka delapan melambangkan kebangkitan.

Gereja Blenduk Semarang memiliki bentuk denah oktagonal yang difungsikan sebagai ruang utama untuk melakukan kebaktian di tiap hari minggu, atau kegiatan publik lainnya. Dari pusat ruangan tersebut, ruang-ruang yang lain tersambung mengikuti arah empat penjuru mata angin. Di sisi Utara dan Timur adalah ruang transept, di sisi Selatan sebagai portico dan foyer, sedangkan ruangan di sisi Barat berfungsi sebagai konsistori.

Berdasarkan hasil pemindaian laser, ada dua macam denah oktagonal, yakni yang berada di inti struktur bangunan dan yang kedua adalah sebagai dinding luar bangunan. Tipe oktagon pertama yang akan dibahas secara rinci di dalam tulisan ini. Konstruksi struktur pada geometri tersebut, mengacu pada sistem portal lengkung (arch) yang saling terhubung antar delapan pilar utama dan dinding pemikul beban. Diidentifikasi bahwa bahan berupa susunan bata dengan selimut plesteran acian yang dicat. Pada bagian kepala pilar terdapat dekorasi. Denah oktagonal memiliki jarak diameter k.l 15,8 meter dan lebar tiap bukaan portal k.l 4,8 meter, sedangkan tinggi ruang k.l 10,8 meter. Ketebalan dinding pemikul sekitar 1 meter dan diameter k.l 65 centimeter. Pada level diatas kepala pilar, struktur oktagonal beralih rupa menjadi bentuk lingkaran yang masih memiliki penebalan dinding di delapan sudutnya. Dalam bahasa Belanda, dinding struktur yang melingkar

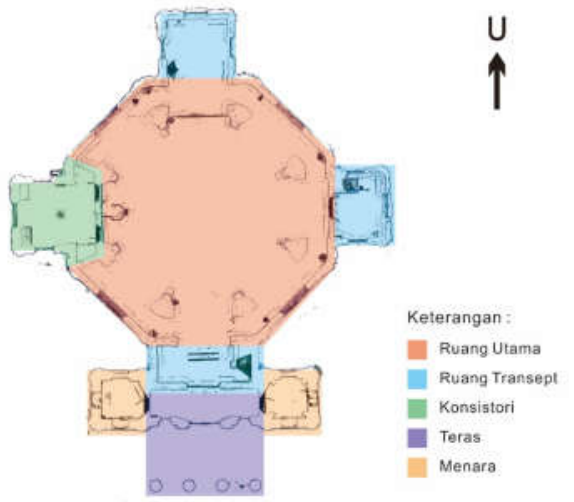

Gambar 12. Pembagian fungsi ruang (Sumber : Dokumentasi ERTIM, 2018)

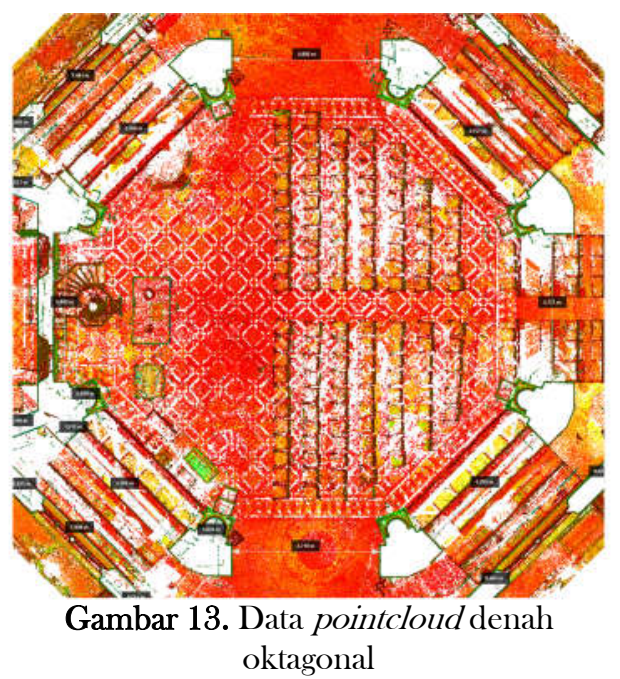

(Sumber : Dokumentasi ERTIM, 2018)

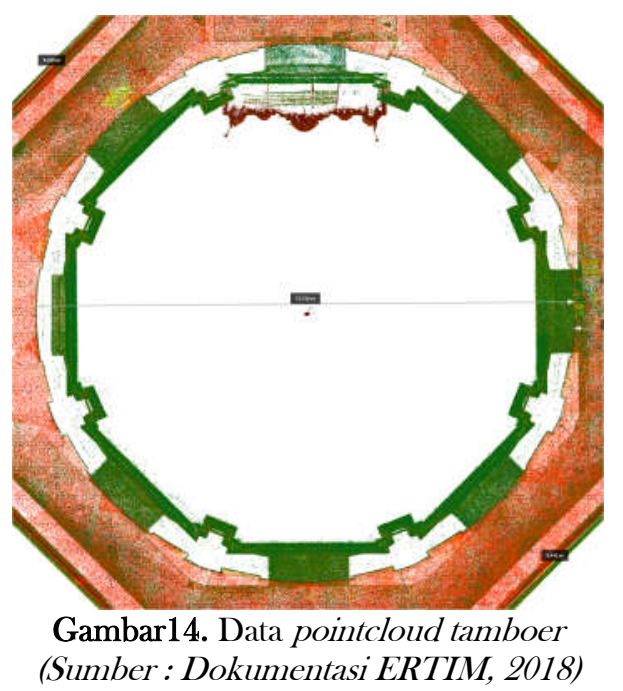




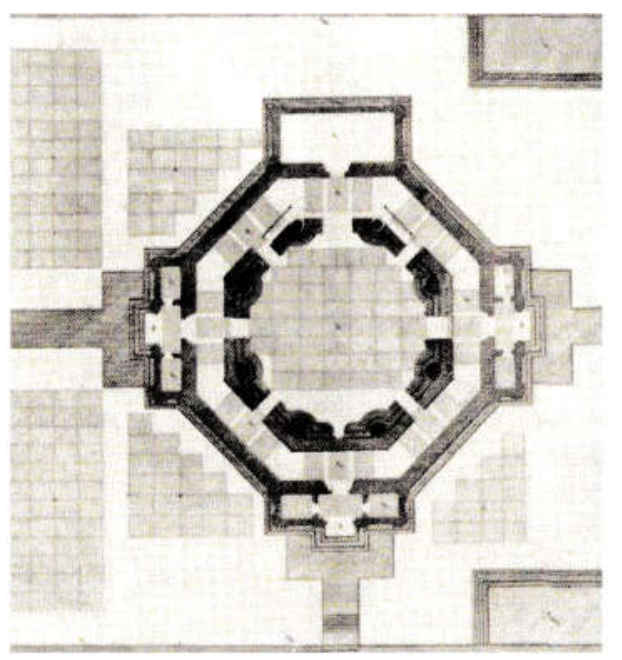

Gambar 15. Denah Gereja Belanda Baru yang digambar oleh J.W. Heydt

(Sumber : Gereja-gereja tua di Jakarta, 2003)

sebagai penghubung atap kubah dengan pilar dibawahnya dikenal dengan istilah tamboer.

Di Batavia pada awal abad ke18 dibangun 'Gereja Belanda Baru' yang memiliki nama lain 'Gereja Kubah' (koepelkerk) dengan bentuk denah oktagonal dan di tiap sudut terdapat tiap pilar untuk menyokong kubah diatasnya (Heuken, 2003: 23). Struktur oktagonal tersebut ditemukan saat pencarian kembali makam J.P. Coen yang terletak di tengah-tengah Museum Wayang. Di lokasi tersebut terdapat batu peringatan yang menyebutkan bahwa titik lokasi tersebut adalah lokasi berdirinya 'Gereja Salib' dari tahun 1640-1732 dan 'Gereja Belanda Baru' dari tahun 1736-1808 (Heuken, 2003: 26). Menilik dari kasus di Batavia, denah oktagonal koepelkerk pertama tersebut memiliki bentuk yang identik dengan denah oktagonal di Gereja Blenduk, perbedaan proporsi hanya terjadi pada bagian sayap-sayap denah utama.

\section{KESIMPULAN}

Melalui referensi sejarah, bentuk denah oktagonal mencirikan ada kegiatan yang mengelilingi sebuah pusat ruang yang dianggap penting atau sakral, yang berada di tengahtengah ruang tersebut. Kegiatan pemusatan tersebut diyakini berhubungan dengan hal yang transenden. Bentuk denah oktagonal dan kubah ruang diatas denah oktagonal telah menjadi ciri banyak tempat suci di dunia. Dalam sejarah konstruksi, alasan munculnya denah oktagonal dan atap kubah adalah untuk mendapatkan ruang dengan bentang lebar. Keragaman model bentuk oktagonal dan atap kubah di tiap situs sangat dipengaruhi oleh kondisi geografi, iklim, ketersediaan bahan, dan latar belakang kebudayaan.

Dalam konteks iklim tropis dan era kolonial di Indonesia, bentuk tersebut hanya muncul di Kota Semarang, abad ke-19. Bila menilik catatan harian V.O.C., kemungkinan besar bentuk tersebut adalah sebuah proses adaptasi dari masalah-masalah teknis yang dihadapi. Kemungkinan besar bentuk dan sistem konstruksi yang kompleks pada atap kubah Gereja Blenduk memerlukan kecermatan teknis dan pemilihan bahan yang tepat. Perbedaan bahan penyusun dengan gereja atap kubah di Belanda dan Jakarta, serta model kubah rusuk cincin diagonal merupakan pertanyaan kritis yang masih perlu diungkap. Sehingga perlu penelitian lanjutan terkait bahan penyusun penutup atap dan rangka atap. Sedangkan denah oktagonal, tipologi pilar, dan portal lengkung hanya dijumpai pada bangunan G.P.I.B. Immanuel Semarang, berbeda dengan GPIB Immanuel 
Jakarta yang memiliki denah lingkaran, pilar kotak, dengan portal cincin, kesamaan hanya terletak pada bahan penyusun yakni konstruksi bata.

Bila diamati kembali, ada kemiripan antara Gereja Blenduk dengan koepelkerk pertama di Batavia. Pertama adalah sama-sama memiliki konsep denah oktagonal dan atap kubah. Yang kedua adalah peletakan ruang konsistori sama-sama di sisi Barat. Namun tetap ada hal yang membedakan, yakni berdasarkan penelusuran Heuken pada koepelkerk Batavia, penutup atap berbahan batu. Sedangkan pada foto-foto lama diketahui pernah berbahan sirap kayu dan yang terakhir dari pelat metal. Orientasi utama Gereja Blenduk menghadap ke Selatan yakni Heeren straat (saat ini Jalan Letjen Soeprapto), sedangkan koepelkerk Batavia menghadap ke lapangan di sisi Timur. Sebagai catatan tambahan, posisi mimbar pada bangunan G.P.I.B.Immanuel di luar Semarang (Jakarta, Malang, dll) yang dibangun pada akhir abad ke-19 sampai dengan awal abad ke-20 berada di sisi Timur.

Arsitektur Gereja Blenduk memiliki konsep desain yang unik, namun masih sedikit penjelasan tentang keunikan wujud arsitekturnya. Hal tersebut wajar, mengingat keterbatasan informasi dan dokumentasi tentang pembangunannya. Masalah keterbatasan ini sangat mungkin didekati dengan ilmu arkeologi bangunan. Dengan melakukan penelitian lanjut, diharapkan muncul narasi baru tentang arkeologi Gereja Blenduk yang bermanfaat dalam mengungkap nilai-nilai pentingnya di masa lalu.

\section{UCAPAN TERIMA KASIH}

Penulis menyampaikan terima kasih kepada pihak pertama yakni, Majelis GPIB Immanuel Semarang yang memberikan kesempatan untuk melakukan survei dan penelitian di Gereja Blenduk. Yang kedua adalah ERTIM Conservation Institute yang telah mengizinkan penggunaan data hasil survei dan buku literatur. 


\section{DAFTAR PUSTAKA}

De Aardbeving. De Locomotief, 16 Desember 1890. Diunduh dari www.delpher.nl

Grussenmeyer, P., Landes, T., Doneus M., Lerma J.L.(2016). Basics of RangeBased Modelling Techniques in Cultural Heritage 3D Recording. Dalam Efstratios Stylianidis \& Fabio Remondino (Eds.), $3 D$ Recording, Documentation and Management of Cultural Heritage (h.305-306). Skotlandia: Whittles Publishing

Hicks, Dan and Audrey Horning.(2006). Historical archaeology and buildings, The Cambridge Companion to Historical Archaeology (h.273-292). Inggris: Cambridge University Press. https://doi.org/10.1017/CCO9781139167321.015

Heuken, Adolf. (2003). Gereja Gereja Tua Di Jakarta. Jakarta: Yayasan Loka Cipta Caraka.

Janse, Herman. (1989). Houten Kappen In Nederland 1000-1940. Delft: Delftse Universitaire Pers

Locale Techniek, Year 1939, Vol. 008, Issue 6. Diunduh dari www.colonialarchitecture.eu .

Moedjiono dan Indriastjario. (2011). Mengenal Gereja Blenduk sebagai Salah Satu Landmark Kota Semarang. Modul, volume 11 nomor 2. https://ejournal.undip.ac.id/index.php/modul/article/view/1458

Protestantsche kerk te Semarang. De Indische Courant, 7 Juni 1928. Diunduh dari www.delpher.nl .

Protestantse Gemeente Te Semarang 200 Jaar. Trouw, 25 Agustus 1953. Diunduh dari www.delpher.nl .

Rond het tweehonderdjarig bestaan van de Koepelkerk. De Locomotief, 19 Agustus 1953. Diunduh dari www.delpher.nl .

Schuller, Manfred. (2002). Building Archaeology. Munchen: ICOMOS. Diunduh dari

https://www.icomos.de/admin/ckeditor/plugins/alphamanager/uploads/pdf/M andSVII.pdf

Soleiman, Yusak. (2012). Pangumbaran Ing Bang Wetan - The Dutch Reformed Church In Late Eighteenth Century Java. Jakarta: BPK Gunung Mulia

Suaka Peninggalan Sejarah dan Purbakala Jawa Tengah. (1989). Laporan Tehnis Pengamatan Gereja Blenduk Semarang. Klaten, Indonesia: Tim Penelitian 
Tanjungsari, C.A., Antariksa, Suryasari, N.(2016). Pelestarian Bangunan Gereja Blenduk(Gpib Immanuel) Semarang. arsitektur e-journal, 9 (1), Juni 2016. http://repository.ub.ac.id/144404/

Wardani dan Triyulianti. (2012). Pengaruh Budaya Indis Pada Interior Gereja Protestan Indonesia Barat Imanuel Semarang. Dimensi Interior. https://www.academia.edu/11476739/PENGARUH_BUDAYA_INDIS_PA DA_INTERIOR_GEREJA_PROTESTAN_INDONESIA_BARAT_IMA NUEL_SEMARANG 